\title{
Structural Modeling of the Top Turonian Reservoir in the Northern Seme Oilfield (Benin, West-Africa)
}

\author{
Gerard Alfred Franck d'Almeida', Christophe Kaki'1, Suzanne Amelina ${ }^{2}$ \\ ${ }^{1}$ Laboratory of Geology, Mines and Environment, Earth Sciences Department, University of Abomey-Calavi, Cotonou, Bénin \\ ${ }^{2}$ Ministry of Water and Mines, Immeuble LOKO, Cotonou, Bénin \\ Email: almeidafranck@hotmail.com
}

How to cite this paper: d'Almeida, G.A.F., Kaki, C. and Amelina, S. (2021) Structural Modeling of the Top Turonian Reservoir in the Northern Seme Oilfield (Benin, WestAfrica). Open Journal of Geology, 11, 682-695.

https://doi.org/10.4236/ojg.2021.1112033

Received: October 26, 2021

Accepted: December 27, 2021

Published: December 30, 2021

Copyright $\odot 2021$ by author(s) and Scientific Research Publishing Inc. This work is licensed under the Creative Commons Attribution International License (CC BY 4.0).

http://creativecommons.org/licenses/by/4.0/ (c) (i) Open Access

\begin{abstract}
The Sèmè oilfield is located in Benin's offshore coastal sedimentary basin, near the Benin-Nigeria border, and contains two important oil bearing structures called "Sèmè North" and "Sèmè South". In this coastal basin, Turonian sandstones of Abeokuta formation (Cenomanian-Turonian to Early Senonian age) form two reservoir units differentiated by two seismic horizons $\mathrm{H} 6$ and H6.5. The H6 seismic horizon represents the upper reservoir unit and is the main reservoir from which, more than 22 million barrels of crude oil had previously been produced in Sèmè oilfield. In order to improve knowledge of field petroleum geology, the present study presents the structural features of this upper reservoir unit. The use of Petrel software modules for the integration of 15 wells data, allowed presenting a structural model and illustrative cross sections that precise the geometry and specifying the structural characteristics of this reservoir unit within Sèmè field. The displayed structural architecture shows that the upper Turonian sandstones unit is composed of 11 layers including 7 reservoir layers (A, B, C1, C2, D1, D2, E) and 4 intra-reservoir layers (1, 2, 3 and 4) controlled by faults systems. The model provides basic framework necessary for geological characterization of the reservoir through a static model. The results of this study can be used for petrophysical modeling, Gross Rock Volume (GRV) determination and technical redevelopment of the field.
\end{abstract}

\section{Keywords}

Sèmè Oilfield, Abeokuta Formation, H6 Horizon, Petrel Software, Structural Modeling, Layers 


\section{Introduction}

The Offshore Benin Basin (OBB), which includes the Sèmè oilfield, belongs to the Benin Coastal Basin, one of the coastal basins of the "Dahomey Embayment" [1]-[6]. The Dahomey Embayment (from western Nigeria to eastern Ghana), is part of the northern Gulf of Guinea a prolific petroleum province where many fields were discovered on the continental shelf or in waters less than 2000 meters deep. The Upper Cretaceous petroleum system with Turonian sandstones reservoirs is the most active over the province [7]. Within Sèmè oil field, Turonian sandstones of Abeokuta formation consist of $28 \%$ clay and $70 \%$ sand. Composed of quartz, calcite, dolomite and rutile, these sandstones have good porosity (18\%) and were exploited from 1982 to 1998 . During these 16 years of operation, only $22 \%$ of the estimated reserves at the time were produced. In 1998, while crude oil world prices were very low, oil production in this field was accompanied by large volumes of water. Water production from the reservoir gradually reached $90 \%$. This situation led to the cessation of production activities and the definitive closure of the field. Nowadays, scientific and technical progresses in the oil industry allow better characterizing hydrocarbon reservoirs and revaluating the residual reserves of a field [8]. According to the significant increased interest and exploration activity in the region [9], the present study aims to define the structural features of the upper part (named H6 seismic horizon) of the sandstones units through a geological modelling using seismic sections, wells data and Petrel software. As part of an important modeling of the H6 horizon including geometrical modeling and petrophysical modeling (static model), the objective of this work is to present the first step of this modeling process based on seismic maps and fault interpretation, reservoir layering as well as correlation framework. The study results are necessary for a better understanding of the geometry of this structure and evaluation of his petrophysical characteristics and potentialities.

\section{Study Area}

The Sèmè oil field is located in the north-eastern part of the offshore sedimentary basin of Benin at bathymetries ranging from 27 to $54 \mathrm{~m}$ (Figure 1). With an area of $63 \mathrm{~km}^{2}$, it is positioned $2500 \mathrm{~m}$ from the Benin-Nigeria border and has two oil structures [10].

The stratigraphic chart of the offshore Benin basin is presented in Figure 2. The upper boundary of Abeokuta formation is materialized by the seismic marker $\mathrm{H} 6$ which is usually picked with the influx of immature, medium and coarse predominantly non-calcareous sandstone [11] [12]. The Maastrichtian unconformity cuts into the formation in the eastern most part of the shelf in the vicinity of the Sèmè Field, while the Mid Miocene Unconformity only affects the formation beyond the shelf edge. The lower limit is the $\mathrm{H} 7$ seismic marker corresponding to the unconformity of the top Albian sandstones. Turonian sandstones units are present over the entire shelf area, with the depocenter on the 


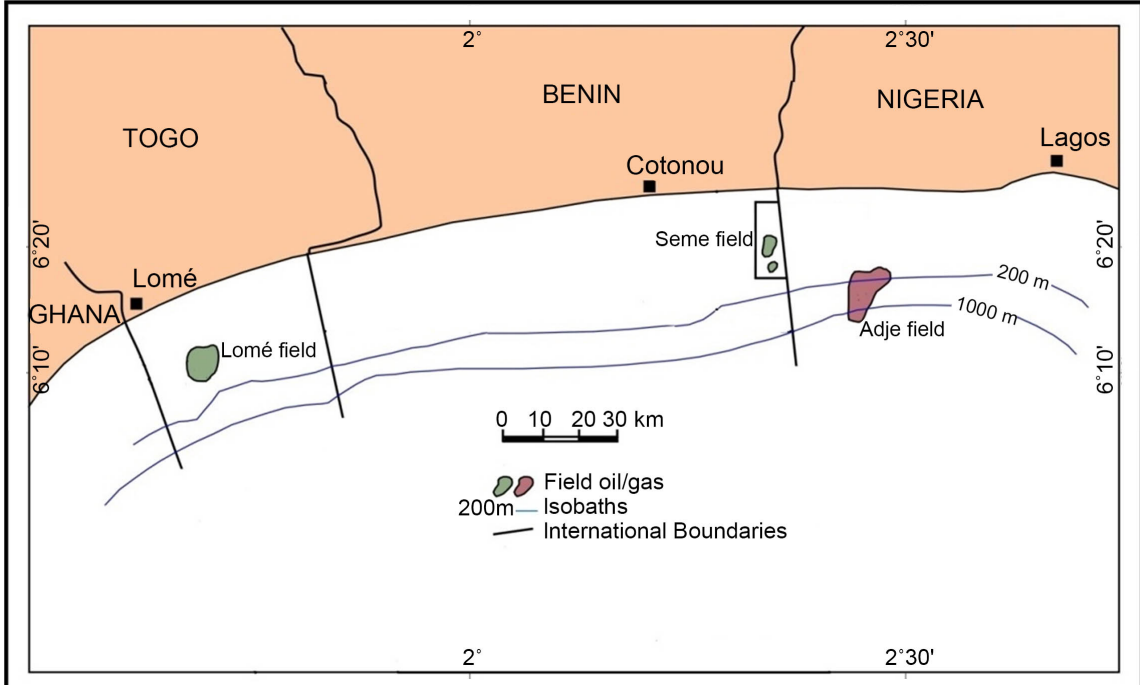

Figure 1. Sèmè field location map with indication of his oil-bearing structures.

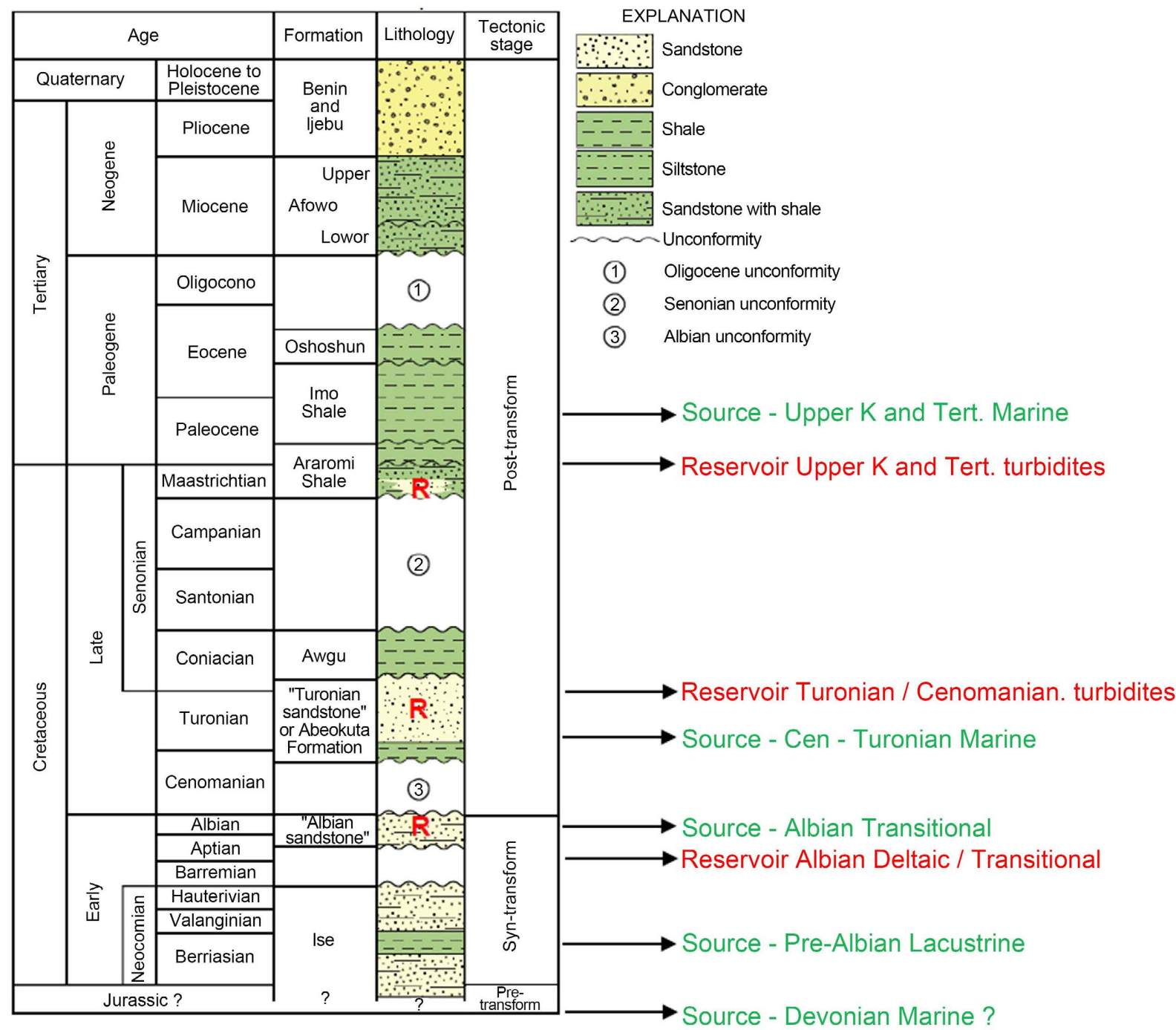

Figure 2. Stratigraphic chart of the offshore Benin basin with indication of formations petroleum characteristics. 
eastern part of the shelf where he attains a thickness close to $1.000 \mathrm{~m}$. These sandstones are light grey to white, generally coarse grained, poorly sorted and with abundant pyrite. Best porosities are in the range of $15 \%-23 \%$. Wells data indicate that Turonian sandstones are deposited from north to south in a distal fan delta environment with extensive marine reworking. For Sèmè field, fluvial environment is predominant for lower part of the unit, below H6.5 seismic horizon [12].

Oil exploration in the coastal sedimentary basin of Benin has led to the discovery of exploitable hydrocarbon accumulations in Turonian sandstone deposits of Abeokuta formation (Cenomanian-Turonian to Early Senonian age). The North Sèmè field is divided into an Eastern, Central and Western area [13]. It is an oil field with an eastern part depleted during 16-year production period (1982-1998) and a central as well western part mostly under developed but nevertheless affected by the eastern production.

\section{Methodology of Study}

The geometrical modeling workflow involved the use of seismic and well data [14] [15] [16] [17] [18]. The study brings together the H-6 reservoir geological information necessary to generate a global 3D field characterization. The study includes a new seismic interpretation and a totally re-interpreted data set made of considerable quantity of past data completed by more recent acquired geological data.

\subsection{Seismic Data}

Seismic sections extracted from acquired lines within the field and their interpretation provides the following data: 1) a depth map at top reservoir (H6 horizon), prepared with the most likely velocity map tied to the well tops and 2) A set of fault polygons representing the intersection of the interpreted fault plans with the H6 horizon, with their main dip angle and azimuth.

\subsection{Well Data}

Data from 15 wells drilled in the northern structure were interpreted. The well log interpretation provides a complete set of composite well logs over the reservoir interval, including when available the gamma ray, neutron density, sonic and resistivity measurement [14] [15] [16] [17] [18]. The studied wells are: S-2, S-3, S-4, S-6, S-7, S-10, S-11, S-C1, S-C2, S-C3, CSE-1, CSW-1, DO-1, DO-2A, DO-A3 (Figure 3 ). Wells data synthesis was done using well log interpretations and correlations.

\subsection{Software Utilization}

The methodology consisted in a complex analysis of data relating to top reservoir (H6 horizon) within the field of Sèmè. The Petrel Software and its numerous function modules were employed [19] [20]. The model was built using Petrel 


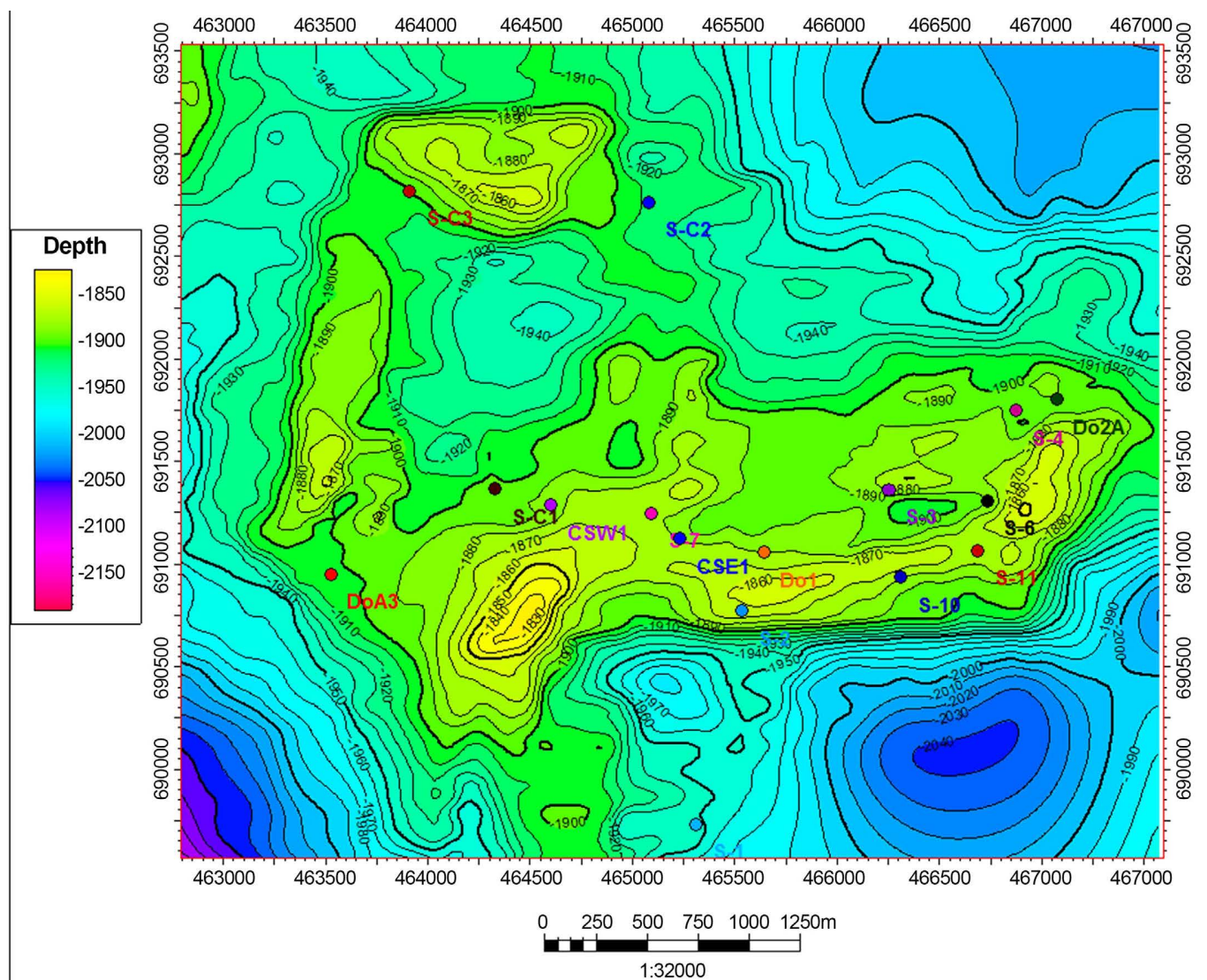

Figure 3. Top reservoir map. Well location correspond to impact on top reservoir.

software applications (Schlumberger) modules to assess and integrate the geological parameters. The generated model was used to display the structural architecture of $\mathrm{H} 6$ horizon including reservoir layers, barriers and fault. The make horizon process (Figure 4) was run using the Top H6 horizon as conformable surface, tied at each well top dataset.

The geomodeling phase is an important phase that unifies, in a 3D interpretative representation, all valuable geologic parameters. The construction of the geomodel involves successive steps, in particular: 1) the geometrical modeling based on seismic maps and fault interpretation and 2) reservoir layering based on wells correlation framework. Thus, the built top reservoir depth map was used as input. The fault pattern/polygons defined at the top of the reservoir with their corresponding fault dips were used to build up the fault sets. Well tops and correlation were used to define the vertical layering of the reservoir unit.

\section{Results of the Study}

\subsection{Top Reservoir Depth Map}

The seismic map used to build the geomodel is the top H6 depth map inferred from a new seismic interpretation performed in 2009. The structural configuration of the top reservoir (H6 Horizon) is characterized by a certain number of low relief independent culminations with clear orientations, either in an east-west 


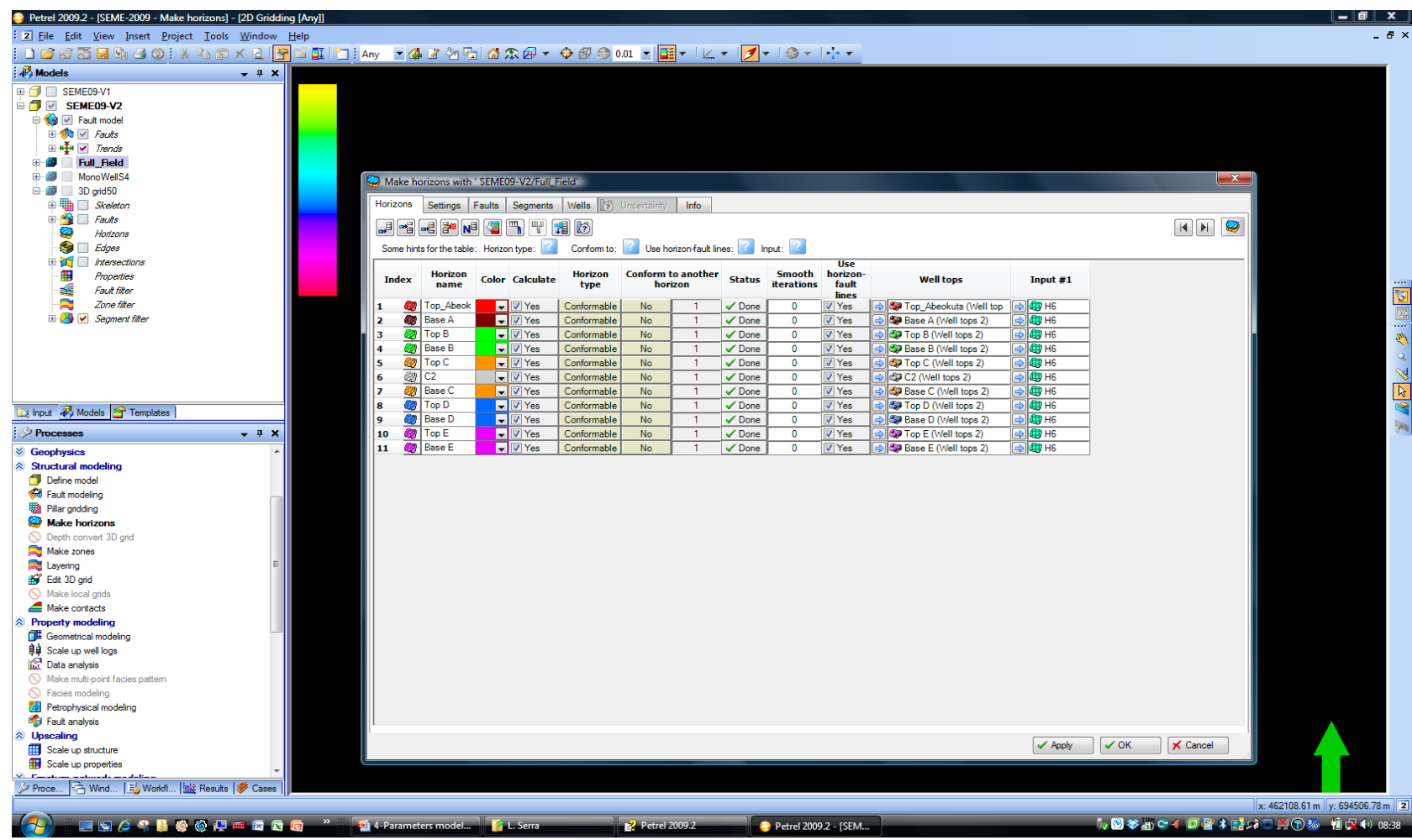

Figure 4. Petrel software interface for full field horizon maker process.

trend or north-northeast to south to southwest trend. Generally, structural continuity is affected by small faults of limited throws, not accurately defined by seismic. The reservoir is truncated to the east in the water bearing zone by erosional surface. Structural uncertainties are mainly related to seismic time to depth conversion as well as vertical depth inconsistencies found in few deviated wells. Seismic interpretation provided a set of fault polygon at top H6 horizon and a map of dip and angle. The fault pattern/polygons defined at the top of the reservoir with their corresponding fault dips were used to build up the fault sets. Wells correlation and Top reservoir map (well location corresponds to impact on top reservoir) gave possibility to present the structural style of the top Abeokuta formation on Sèmè field (Figure 5).

1) Two main E-W faults at North and South of the structure. These faults are limited in their Eastern part by the erosional surface between the H4 and H5 formation. The fault at the South is limited in its western part by a small horst in the central area. Another East-West fault is present at the North of well SC3, defining a closed structure in that area.

2) Different small horst and grabben systems oriented mainly N-S or SW-NE, in particular in the S4 and S10 area.

3) The accident at the south of wells DO1, S3, S6 and S4, has a direction going from East west to nearly North-South with a dip to the north. It is composed of two different faults in continuity and will have a major impact on the grid construction and flow behavior of this producing zone. 


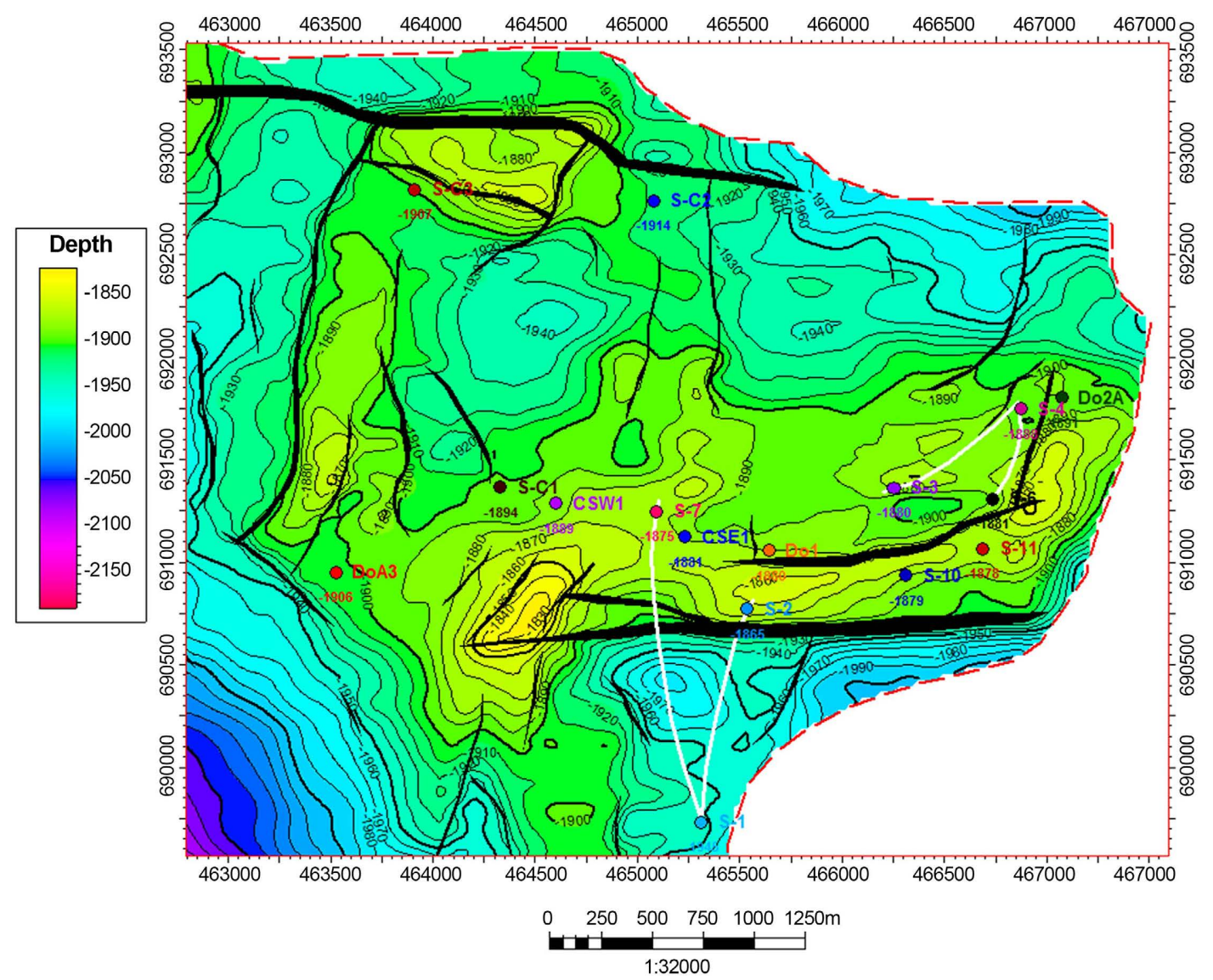

Figure 5. Top H6 depth map with faults and erosional limit.

\subsection{Vertical Layering of the Reservoir Unit}

The vertical gridding was done using the top H6 horizon and the well top markers from the correlation. Well tops and correlation were used to define the vertical layering of the reservoir unit (Figure 6). Layer limits are all set conformably to the top H-6 surface: Top Abeokuta, Base A, Top B, Base B, Top C1, Top C2, Base C, Top D, Base D, Top E and Base E.

Thus, eleven explicit zonation were then built: 7 reservoir units $(A, B, C 1, C 2$, $D, E)$ and 4 barrier units (1, 2, 3 and 4) were delineated. Each of these zones represents one reservoir layer in the grid, except the zone $\mathrm{D}$ that was subdivided into 2 isopach layers. The barriers were defined as explicit layers in order to easily modify their petrophysical properties during the history matching.

The different layers identified are:

Unit A: thin unit $(0-3.2 \mathrm{~m})$ not present in the south east corner (Wells Dol, S2, S3, S10, S11) with fair to good reservoir characteristics.

Barrier 1: shaly event with same extent that unit A. This level appears to have a law sealing properties, with a small break in potential between units $A$ and $B$, unit A being most of the time less depleted than B (i.e. Well S4).

Unit B: good reservoir unit with an average thickness of $4.4 \mathrm{~m}$, showing a global thickening from South-East to North-West. 


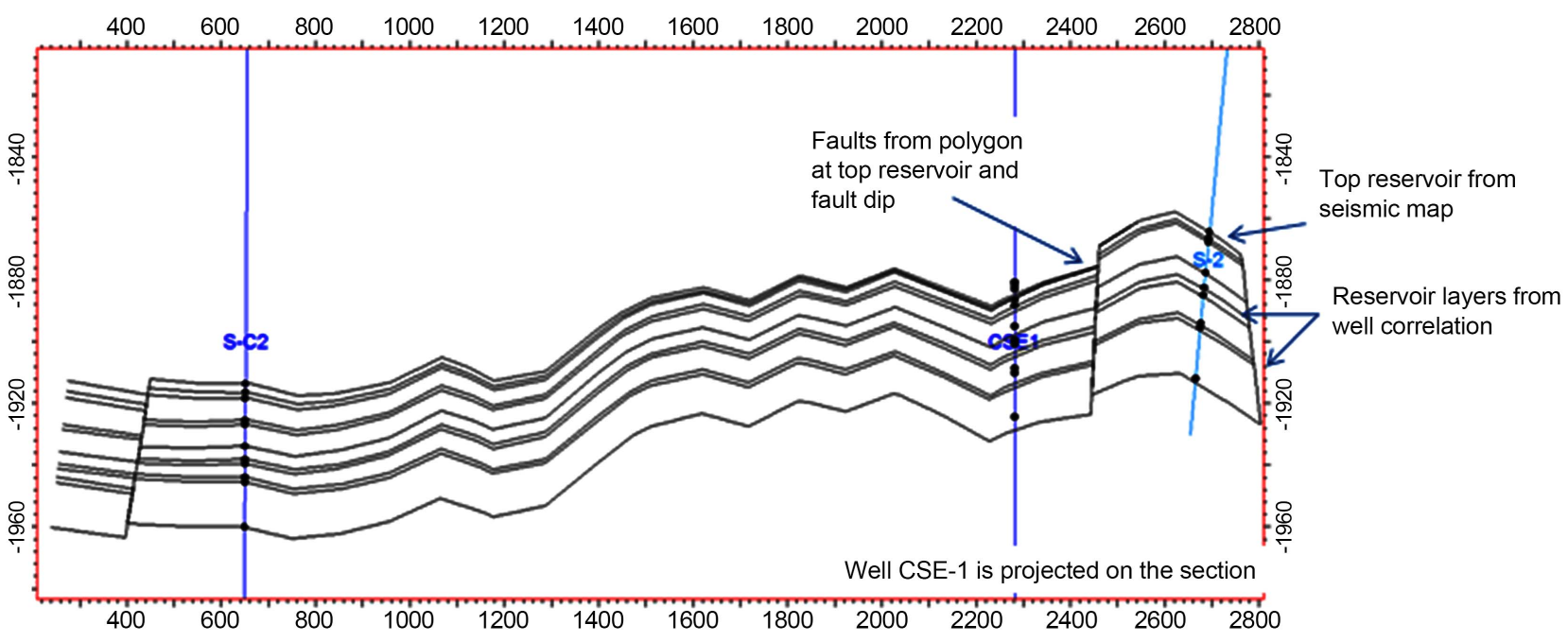

Figure 6. Illustration of the geometrical modeling workflow.

Barrier 2: This level is most of the time corresponding to a high Gamma ray interval. Its thickness is between 1 and $2.5 \mathrm{~m}$. This level corresponds to a break in pressure potential between units $\mathrm{B}$ and $\mathrm{C}$. This break shows in some cases the unit C more depleted than B (i.e. Wells S4, SC-2, SC-3), or in some other cases the unit $\mathrm{C}$ less depleted than $\mathrm{B}$ (i.e. Wells S6, S11).

Unit C1: With a global thickness from 5 to $8 \mathrm{~m}$, this level is a very good massive reservoir, produced in many wells.

Unit C2: Good massive reservoir around $5 \mathrm{~m}$ thick. $\mathrm{C} 1$ and $\mathrm{C} 2$ units limit was defined based on a small radioactive level, not always visible. There is no noticeable difference in pressure potential between these two units.

Barrier 3: This level corresponds to the limit between the $\mathrm{C}$ and $\mathrm{D}$ reservoir units. It is most of the time corresponding to a shaly interval (S4, S6, S3, S10), but with not so clear log response in some cases (S11). This level was cored in well S2, and is described as a 3 meter thick shaly interval, finely laminated. There is most of the time a pressure gradient break above and below this level, with the C level more depleted than the D.

Unit D: thick massive reservoir unit (around $10 \mathrm{~m}$ ), with occasionally some shaly intervals (S3). The unit D can be subdivided into 2 isopach layers (D1 and D2).

Barrier 4: This interval is the main barrier level of the Abeokuta complex, always indicating an important pressure gradient break, between the depleted D unit above, and the non or very poorly depleted $\mathrm{E}$ unit bellow. It corresponds in some well with a shaly interval (S6, S7, SC-3), but has often a not clear log signature $(\mathrm{S} 3, \mathrm{~S} 10 \ldots)$. This barrier doesn't seem to be correlated with a consistent singular sedimentological event, but most probably to a relay in multiple sealing intervals. This level was cored in well S2, and probably corresponds to a half meter shaly interval (2304 - 2304.5 core depth). Note that this well has no pressure data to prove the correlation of barrier 4 , and a possible uncertainty on the core to well depth shift. 
Unit E: This unit is thick ( 15 to $20 \mathrm{~m}$ ) with occurrence of several shaly events. The base of this unit was mainly defined on the presence of a shaly level, not always clear. There is no pressure break visible above and below this lower limit.

In some cases, some uncertainties remain concerning the exact location of some markers, especially when no or poor pressure points are available (well S2, $\mathrm{DO} 1, \mathrm{DO} 2 \mathrm{~A}$ ), or when these pressure points were taken late after end of production (CSE1, CSW1). In those cases, the well log data were mainly used with the uncertainties discussed above.

Using Petrel software applications (Schlumberger) modules, the limits and trends of the reservoir architecture and a $100 \times 100 \mathrm{~m}$ grid was defined. Such refinement is sufficient to take into account the observable geological heterogeneities. Thus, pillar gridding process, grid skeleton and grid segmentation allow to build the 3D grid view of H6 horizon (Figure 7). Generally, structural continuity is affected by small faults of limited throws, not accurately defined by seismic.

The H6 horizon thickness is generally less than $100 \mathrm{~m}$. The $3 \mathrm{D}$ grid view of H6 horizon is illustrated by the following geological section across the structure (Figures 8-13). The North-South orientation sections (Figures 8-10) make it possible to notice that in the direction of the sea the H6 horizon sinks following the bottom morphology of the basin.

East-West cross sections (Figures 11-13) show that, the H6 horizon has the shape of a faulted anticline less faulted and more flat in the vicinity of the southern structure.

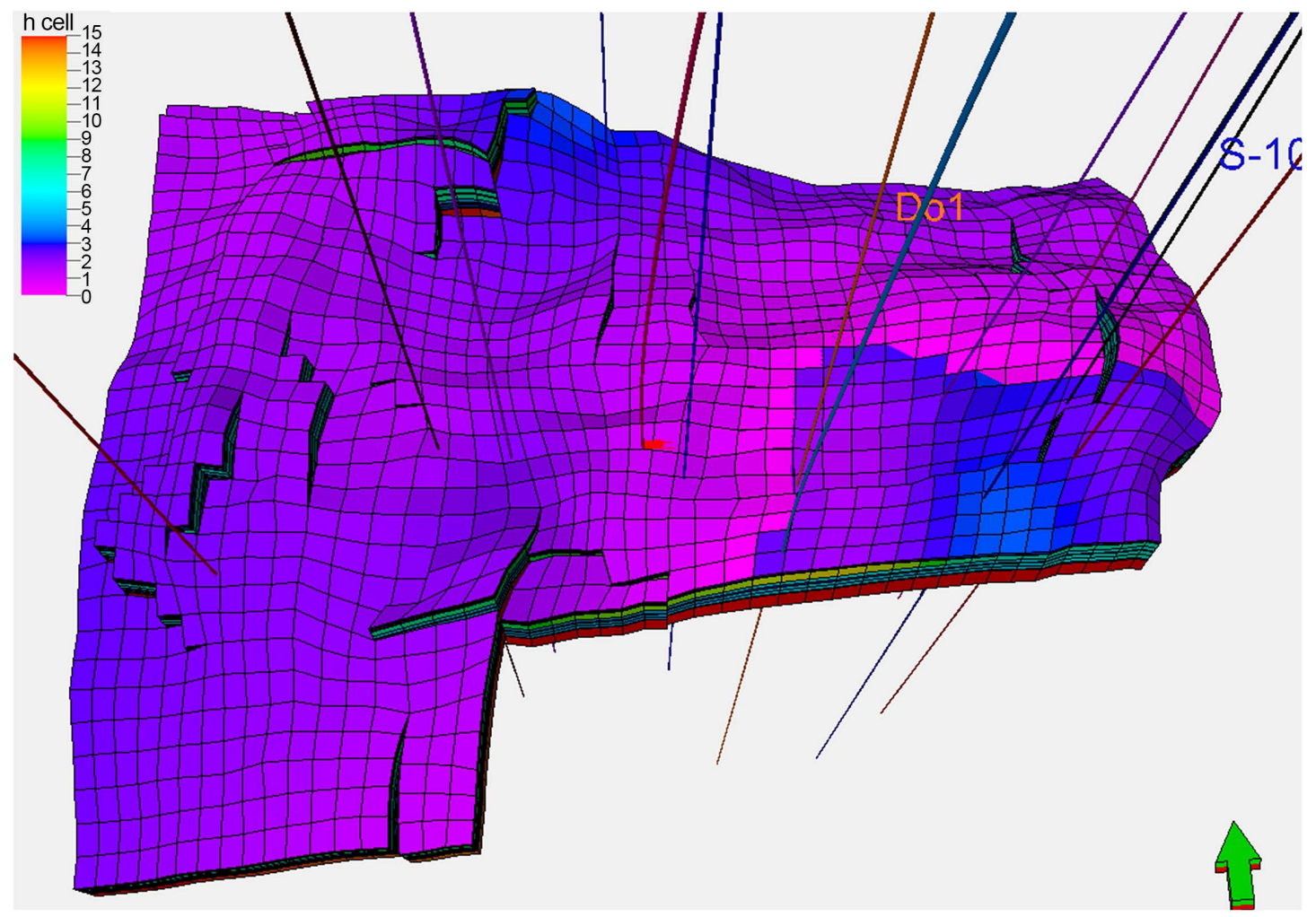

Figure 7. 3D grid view of $\mathrm{H} 6$ horizon. 


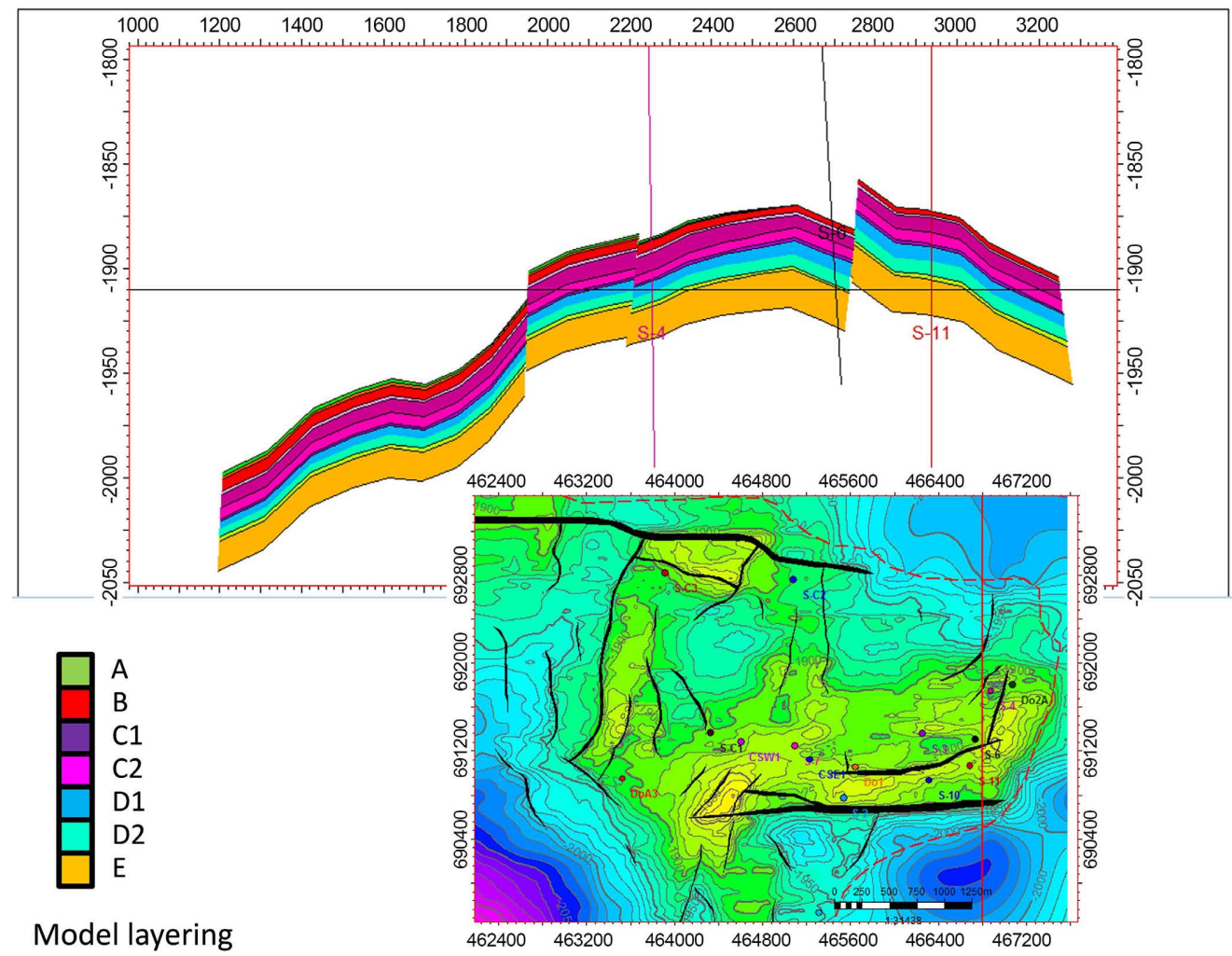

Figure 8. Cross section N-S East.

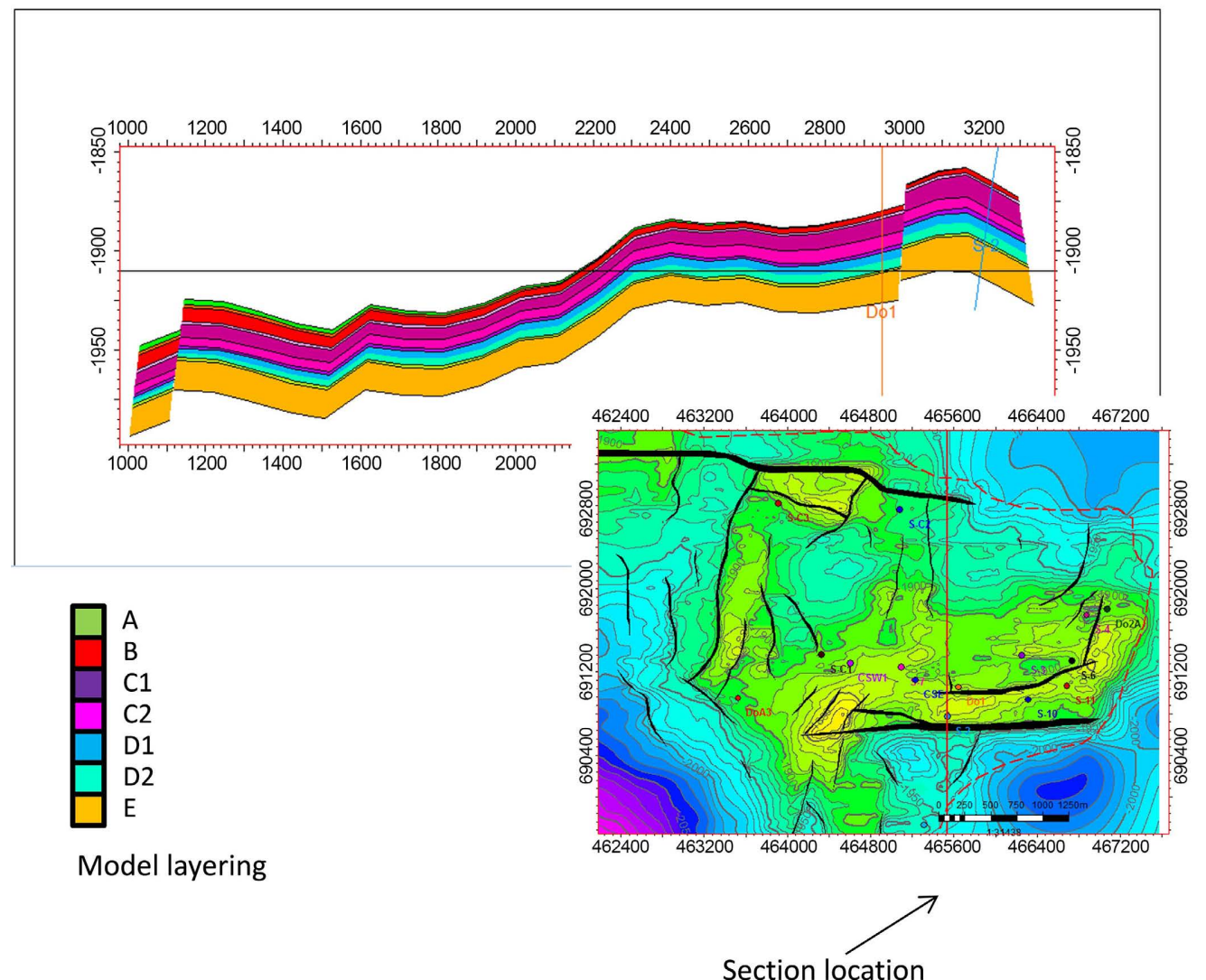

Figure 9. Cross section N-S Central. 


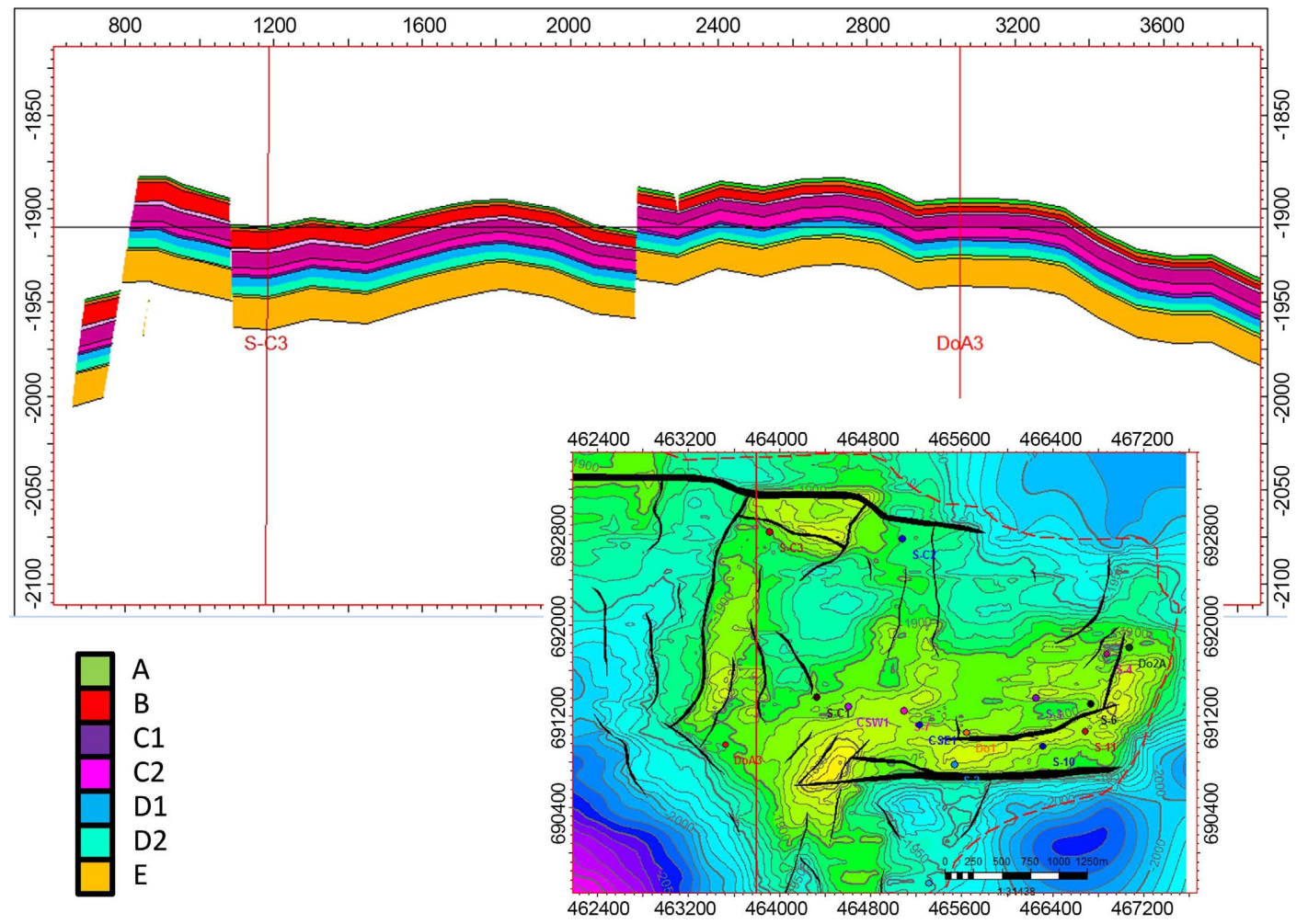

Model layering

Figure 10. Cross section N-S West.

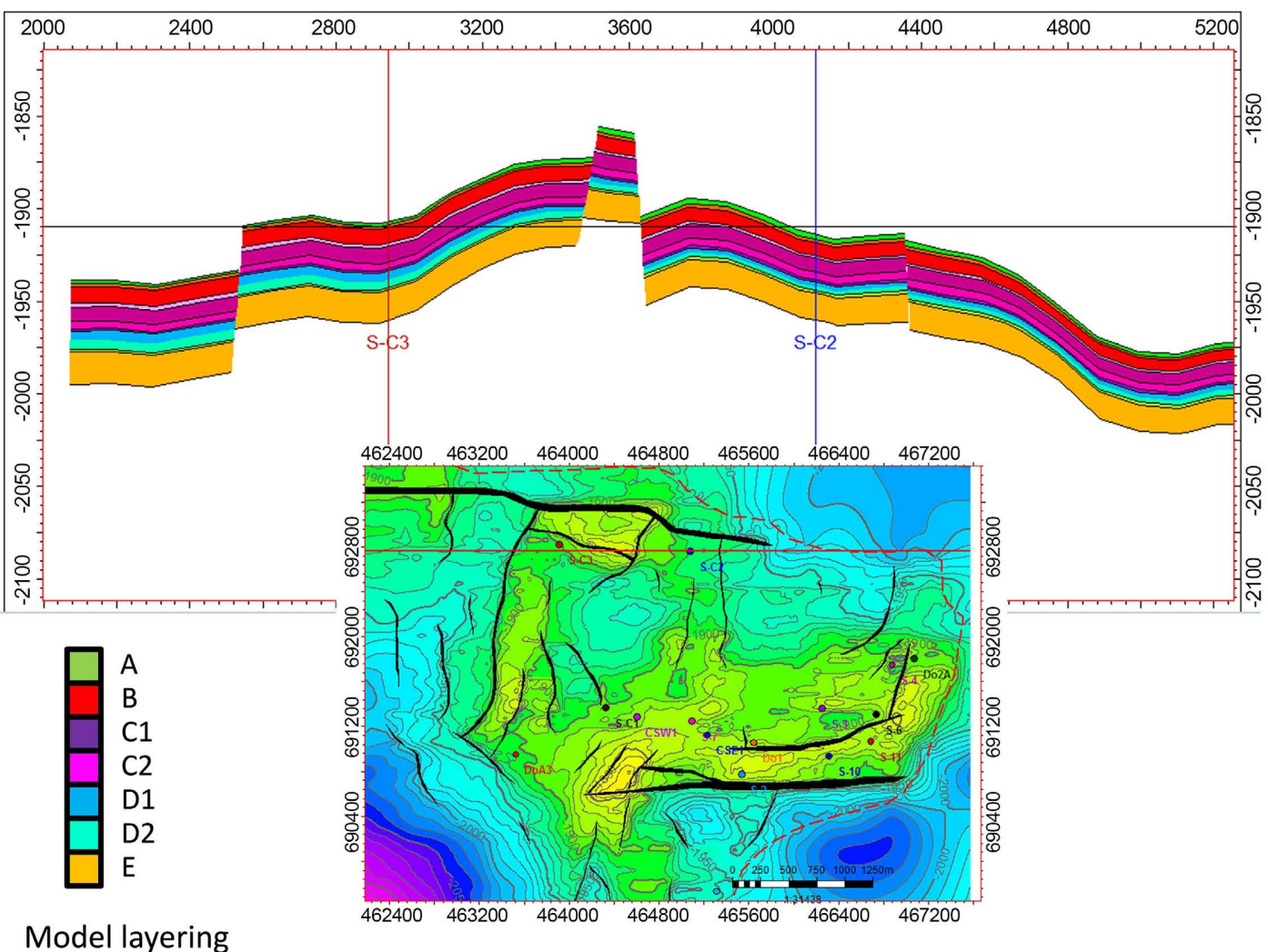

Figure 11. Cross section E-W North. 
G. A. F. d'Almeida et al.

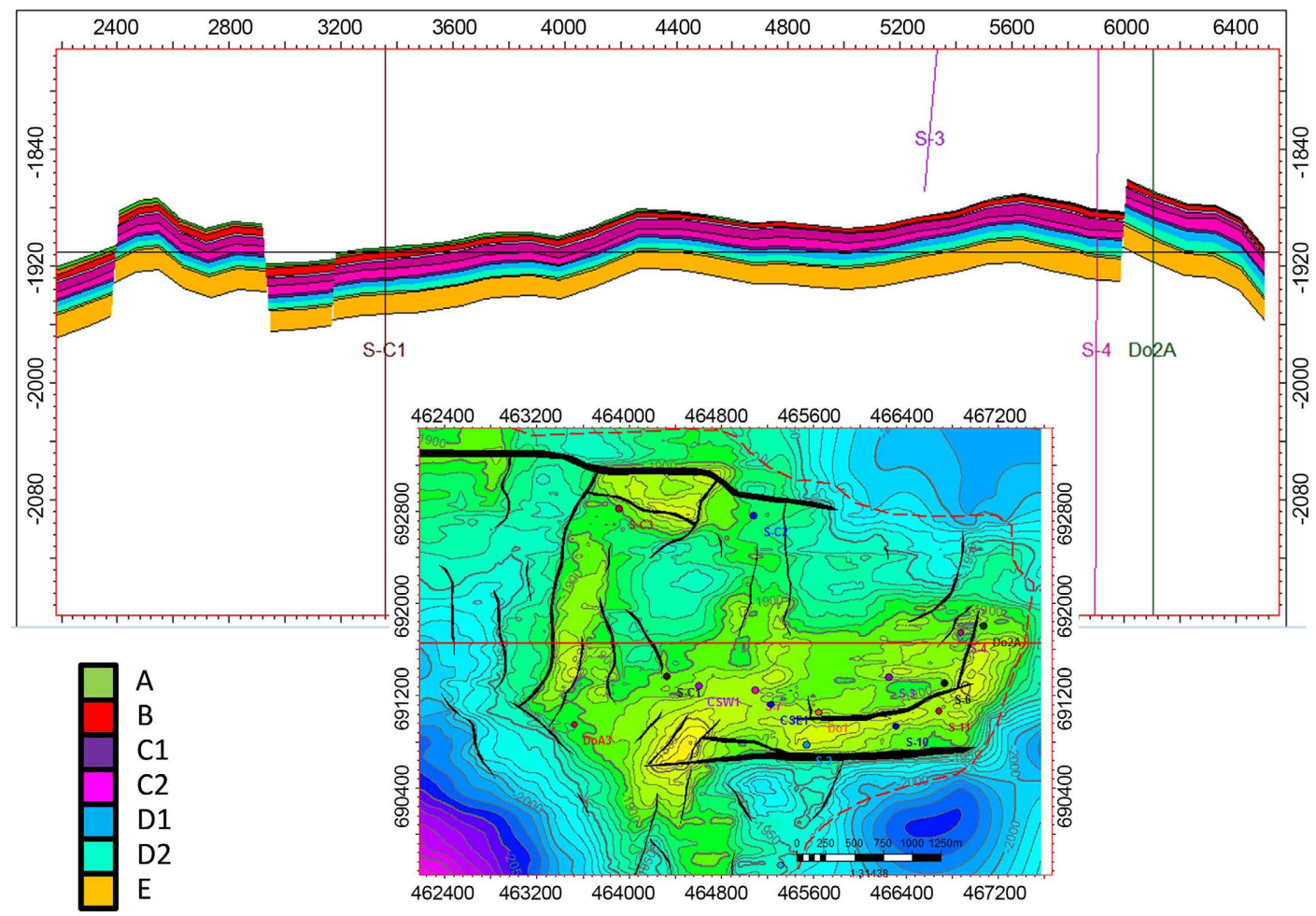

Model layering

Figure 12. Cross section E-W Central.

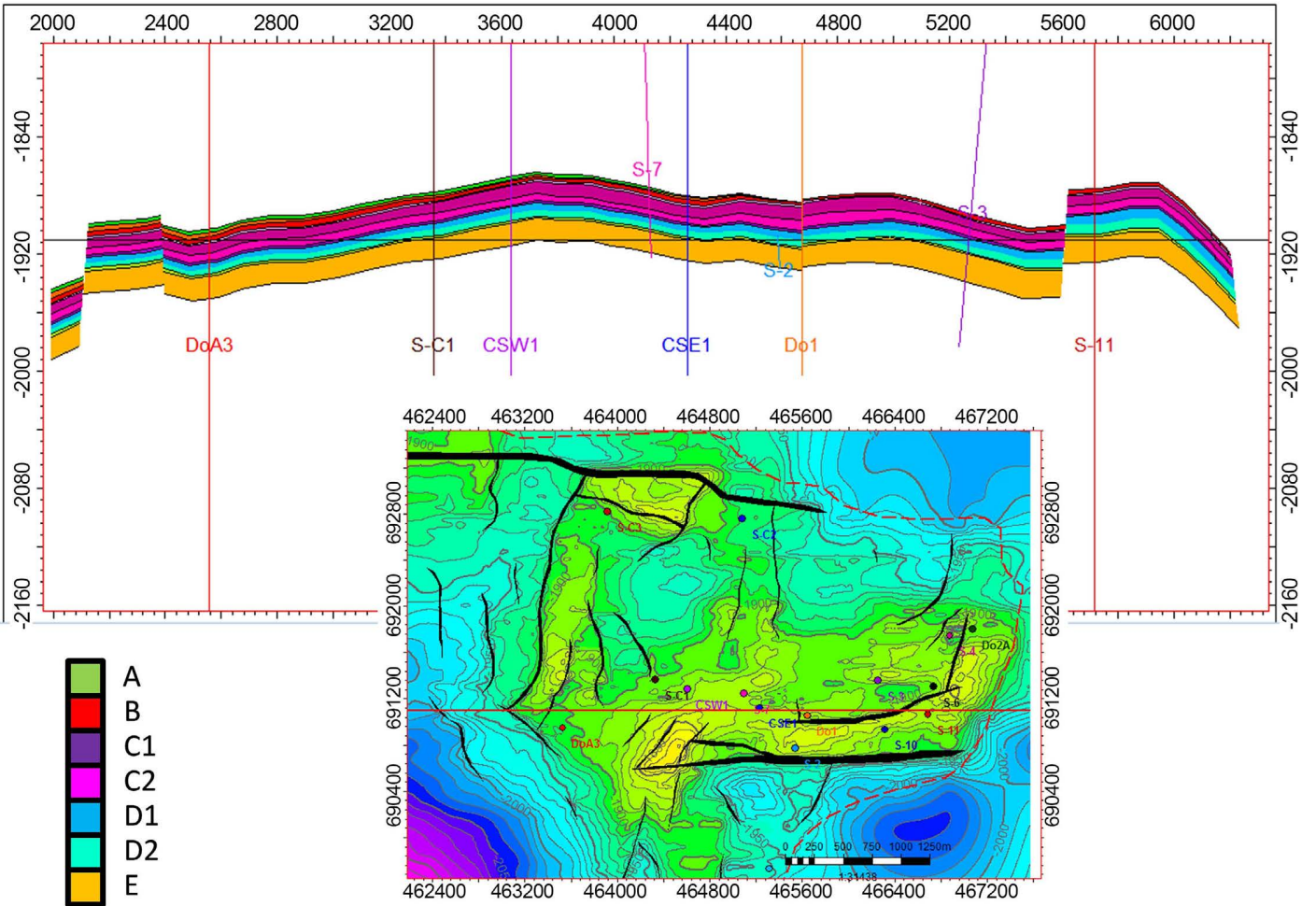

Model layering

Figure 13. Cross section E-W South. 
Vertical layering of $\mathrm{H} 6$ horizon was previously done using gamma ray wire line of a limited number of wells (S3, S4, S7 and SC3) [7]. According to [7] only one well (SC3) located in West Sèmè North give possibility to differentiate 11 layers with a global thickness of $220 \mathrm{~m}$. From other wells the number of layers vary from one (well S7) to six (well S4). The presence of horizontal barriers raised the question of the existence of several independent reservoir units, with possibility of different contact level. It was observed that for every well, the E reservoir unit is disconnected from the upper unit. On the other hand, the reservoir units $\mathrm{A}, \mathrm{B}, \mathrm{C}$ and $\mathrm{D}$ constituting one reservoir tank with an original OWC at $1910 \mathrm{~m}$ TVD remain the most likely assumption.

\section{Conclusion}

The structural modeling of the top Abeokuta formation (H6 horizon) using Petrel exploration software has shown that the "Sèmè North" H6 horizon is formed of 11 layers (7 main reservoir layers: A, B, C1, C2, D1, D2, E) and 4 thin intra-reservoir layers. Layer $\mathrm{A}$ is partially absent. Thus, the study brings together the H-6 reservoir geological information. Its displays the structural architecture of the Turonian sandstones unit including reservoir layers, barriers, faults systems and provide the basic framework necessary to generate a global 3D field characterization. The seismic interpretation and time to depth conversion have been significantly improved by the addition of $3 \mathrm{D}$ into the seismic survey. However, critical structural uncertainties at the top H6 map still remain.

\section{Acknowledgements}

We are grateful to Engineer Senior ATCHADE J. J., former General Manager of Beninese Society of Hydrocarbons for supplying the seismic and wells data. A great thank to the staff of Schlumberger office in Lagos (Nigeria) for preceding trainings on Petrel software.

\section{Conflicts of Interest}

The authors declare no conflicts of interest regarding the publication of this paper.

\section{References}

[1] Billman, H.G. (1992) Offshore Stratigraphy and Paleontology of the Dahomey Embayment, West Africa. Nigerian Association Petroleum Explorationists Bulletin, 7, 121-130.

[2] Brownfield, M.E. and Charpentier, R.R. (2006) Geology and Total Petroleum Systems of the West-Central Coastal Province (7203), West Africa. U.S. Geological Survey Bulletin, No. 2207-C, U.S. Geological Survey, Reston, 52 p.

[3] D’Almeida, G.A.F., Kaki, C., Yalo, N. and Amelina, S. (2016) Analyse de la subsidence dans le bassin offshore du Bénin, Afrique de l'Ouest. Afrique Science, 12, 200-212. http://www.afriquescience.info.

[4] Kaki, C., D’Almeida G.A.F., Yalo, N. and Amelina, S. (2012) Geology and Petro- 
leum Systems of the Offshore Benin Basin (Benin-West Africa). Oil \& Gas Science and Technology-Revue de IFP Energies nouvelles, 68, 363-381. https://doi.org/10.2516/ogst/2012038

[5] Moulin, M., Aslanian, D. and Unternehr, P. (2010) A New Starting Point for the South and Equatorial Atlantic Ocean. Earth-Science Reviews, 98, 1-37. https://doi.org/10.1016/j.earscirev.2009.08.001

[6] South Atlantic Petroleum Company (2010) North Seme Field Geological (Static) Modeling Report. South Atlantic Petroleum, Lagos, Nigeria, 70 p.

[7] Beicip-Franlab (1994) Etude géologique et évaluation des réserves du champ de Sèmè, Projet Pétrolier de Sèmè (P.P.S.), Volume I. Paris, 157 p.

[8] Verney, P. (2009) Interprétation géologique des données sismiques par une méthode supervisée basée sur la vision cognitive. PhD Thesis, Editions TECHNIP, Paris, 276 p.

[9] Kogbe, C.A. and Mehes, K. (1986) Micropaleontology and biostratigraphy of the coastal basins of West Africa. Journal of African Earth Sciences, 5, 1-100. https://doi.org/10.1016/0899-5362(86)90021-7

[10] Amelina, S. (2008) BENIN, le demi-verre de pétrole. Tunde, Cotonou, $196 \mathrm{p}$.

[11] Bumby A.J. and Guiraud R. (2005) The Geodynamic Setting of the Phanerozoic Basins of Africa. Journal of African Earth Sciences, 43, 1-12.

https://doi.org/10.1016/j.jafrearsci.2005.07.016

[12] SAGA Petroleum (1994) Evolution du bassin sédimentaire côtier du Bénin. SAGA Petroleum, Denver.

[13] Gnammi Yoro, I. (2013) Etude approfondie de l'horizon H6 et son redéveloppement au niveau du champ de Sèmè. Mémoire de master en "Géosciences et Applications", Université d'Abomey-Calavi, Benin, $84 \mathrm{p}$.

[14] SAGA Petroleum (1983) Final Well Report Geological and Engineering Seme2. SAGA Petroleum, Denver, $77 \mathrm{p}$.

[15] SAGA Petroleum (1983) Final Well Report Geological and Engineering Seme3. SAGA Petroleum, Denver, 123 p.

[16] SAGA Petroleum (1983) Final Well Report Geological and Engineering Seme4. SAGA Petroleum, Denver, $114 \mathrm{p}$.

[17] SAGA Petroleum (1985) Final Well Report Geological and Engineering Seme7. SAGA Petroleum, Denver, $98 \mathrm{p}$.

[18] SAGA Petroleum (1985) Final Well Report Geological and Engineering SC3. SAGA Petroleum, Denver, $76 \mathrm{p}$.

[19] Schlumberger (1986) Log Interpretation Charts. Schlumberger, Houston, $125 \mathrm{p}$.

[20] Schlumberger (2013) Petrel Fundamentals: Training and Exercise Guide. NEXT Company, Houston, 364 p. https://www.slb.com/petrel 